\title{
Evaluation of Australian wheat genotypes for response to variable nitrogen application
}

\author{
Saba Mahjourimajd (iD • Haydn Kuchel • \\ Peter Langridge • Mamoru Okamoto
}

Received: 20 August 2014 / Accepted: 28 September 2015 / Published online: 6 October 2015

(C) The Author(s) 2015. This article is published with open access at Springerlink.com

\begin{abstract}
Aims The key aim was to assess the genetic variation for nitrogen $(\mathrm{N})$ response and stability in spring wheat germplasm to determine the scope for improvement of nitrogen use efficiency (NUE) under water-limited, low yielding conditions. A further aim was to evaluate NUE stability and NUE-protein yield (PY) as suitable NUErelated traits for selection.

Methods The traits measured included grain yield (GY, $\mathrm{kg} \mathrm{ha}^{-1}$ ) and NUE (kg GY kg-1 N) under varying $\mathrm{N}$ applications at all sites, and NUE for protein yield (NUE-PY), harvest index and plant height at some sites.
\end{abstract}

Responsible Editor: Ad C. Borstlap.

Electronic supplementary material The online version of this article (doi:10.1007/s11104-015-2694-z) contains supplementary material, which is available to authorized users.

S. Mahjourimajd $(\bowtie) \cdot$ P. Langridge $\cdot$ M. Okamoto Australian Centre for Plant Functional Genomics (ACPFG), The University of Adelaide, PMB1, Glen Osmond, SA 5064, Australia e-mail: sabamajd57@gmail.com

\section{P. Langridge}

e-mail: peter.langridge@adelaide.edu.au

M. Okamoto

e-mail: mamoru.okamoto@acpfg.com.au

H. Kuchel

Australian Grain Technologies, PMB1, Glen Osmond, SA 5064, Australia

e-mail: haydn.kuchel@ausgraintech.com
In addition, two of the trials used two seeding rates to provide an assessment of the impact of plant density on NUE.

Results Genetic variation was significant for all traits studied. Grain yield was affected by both genotype $(\mathrm{G})$ and $\mathrm{N}$ rate and the interaction between the two. Interestingly, harvest index and height showed no direct response to varying $\mathrm{N}$ applications. However, for these traits, there was a significant $G$ effect and $N$ response $(G \times N$ interaction).

Conclusions Increasing $\mathrm{N}$ inputs led to variable responses for GY at different sites. Importantly, genetic variation in $\mathrm{N}$ response was detected. The information and screening techniques will enable plant breeders to select wheat genotypes that show a consistent response to high $\mathrm{N}$. There is clear scope to improve NUE in spring wheat grown in low yielding environments.

Keywords Wheat · Nitrogen response - Nitrogen use efficiency $\cdot$ Grain yield $\cdot$ Protein yield

$\begin{array}{ll}\text { Abbreviations } \\ \text { N } & \text { Nitrogen } \\ \text { NUE } & \text { Nitrogen use efficiency } \\ \text { G } & \text { Genotype } \\ \text { GY } & \text { Grain yield } \\ \text { SR } & \text { Seeding rate } \\ \text { PY } & \text { Protein yield } \\ \text { H } & \text { Plant height } \\ \text { HI } & \text { Harvest index }\end{array}$




\section{Introduction}

The global rate of consumption for nitrogen $(\mathrm{N})$ fertiliser is higher than for any other nutrient ( $62 \%$ of all fertiliser application is N) (FAO 2011). However, studies have demonstrated that cereals, including wheat, cannot effectively utilise the supplied $\mathrm{N}$ and it is estimated that only $40-60 \%$ of $\mathrm{N}$ supplied is absorbed by crops (Craswell and Godwin 1984; Hodge et al. 2000; Sylvester-Bradley and Kindred 2009). This low uptake of $\mathrm{N}$ can affect nitrogen use efficiency (NUE) and lead to high production costs, loss of $\mathrm{N}$ from the soil by leaching, contamination of surface and underground water (Mizuta et al. 2004), and gaseous emissions such as nitrous oxide, a major greenhouse gas (Harrison and Webb 2001). In addition, the poor use of supplied $\mathrm{N}$ may lead to insufficient $\mathrm{N}$ availability for plants at times of peak demand with consequent yield reduction. Genotypes show different behaviour with different levels of available $\mathrm{N}$ across sites and growing seasons (Le Gouis and Pluchard 1996; Gallais and Coque 2005; An et al. 2006). The two main components of NUE, $\mathrm{N}$ uptake efficiency and $\mathrm{N}$ utilisation efficiency, should both be taken into account to optimise NUE in plants. Both components are controlled by a combination of genetic and environmental factors across genotypes (Gallais and Coque 2005; Laperche et al. 2006; Coque et al. 2008).

A prime challenge for plant breeders is screening and selection of genotypes for consistent $\mathrm{N}$ response and high NUE in order to reduce $\mathrm{N}$ losses and maximise yield and other desirable traits. To meet this challenge, we need a detailed understanding of available genetic variation in $\mathrm{N}$ response, using field and controlled environment approaches to assess the responsiveness of genotypes to supplied $\mathrm{N}$, and dissection of $\mathrm{N}$ metabolic pathways. However, NUE and N response are complex traits which show inconsistent trends across years and sites (Hirel et al. 2001; Chen et al. 2004; Brennan et al. 2014). Accordingly, the integration of agronomic, physiological and molecular data will be important for selection of the best genotypes with high NUE in specific environments (Hirel et al. 2007; Pathak et al. 2008; Sylvester-Bradley and Kindred 2009). Several researchers have considered the yield response of genotypes under varying growth conditions. Since $G \times E$ seriously complicates genetic improvement for grain yield (GY) in wheat (Cooper et al. 1996), Podlich et al. (1999) proposed a selection strategy to accommodate $\mathrm{G} \times \mathrm{E}$ via computer simulation in multienvironment trials.
The goal of NUE improvement is to increase grain production via either direct selection for GY or indirect selection for yield components. For example, there is a significant relationship between yield and biomass and thousand kernel weight with application of $\mathrm{N}$ fertiliser (Serrano et al. 2000; Groos et al. 2003). Kanampiu et al. (1997) reported that genotypes with high harvest index (HI; grain produced divided by the total dry biomass) demonstrated a higher NUE and potentially increased GY (Raun and Johnson 1999). Nitrogen assimilation, particularly close to anthesis and during remobilisation into the grain, affects the duration of grain filling and therefore yield (Barbottin et al. 2005), and highlights the need for sufficient $\mathrm{N}$ supply throughout crop growth. One of the main components of NUE is expected to be HI (Le Gouis et al. 2000).

Nitrogen and water deficit can affect GY differently but in most wheat production areas the two factors are likely to be linked. Co-occurrence of low $\mathrm{N}$ and low water availabilities has been reported for the Mediterranean-type environment of South Australia (Angus and Van Herwaarden 2001; Sadras et al. 2012). Relatively little is known about the interaction of water stress and $\mathrm{N}$ availability or the effects of the combination of these two factors on yield components. Water deficit and high temperatures commonly occur during flowering and grain filling in the production environments of southern Australia. In the region used for this study, crops are sown after autumn rainfall when good soil moisture is available for crop establishment and early vegetative growth. Varieties able to take up $\mathrm{N}$ during early growth but which restrict tillering and vegetative growth are less susceptible to the late season drought but need to efficiently remobilise the $\mathrm{N}$ during grain filling (Liao et al. 2004). The main aim of this study was to assess the genetic variation for $\mathrm{N}$ response and stability in spring wheat germplasm to determine the scope for improvement of NUE under water-limited, low yielding conditions. A further aim was to evaluate NUE stability and NUE-protein yield (PY) as suitable NUE-related traits for selection.

\section{Materials and methods}

Field experiments

Five NUE field trials were conducted in a split-plot design with three replicates at varying rates of $\mathrm{N}$ 
application in different sites of South Australia in 2010 and 2011. Nitrogen treatments were applied to the main plots with the genotypes grown in sub-plots. Nitrogen rates varied between 18 and $87 \mathrm{~kg} \mathrm{~N} \mathrm{ha}^{-1}$ at either 3 or 4 levels. At two sites, two different seeding rates were also used (Table 1). Urea $\mathrm{N}$ fertiliser was applied once at planting time. Soil samples were taken from the field before planting, and analysed for a range of characters including soil mineral $\mathrm{N}$ levels (CSBP soil and plant laboratory, Bibra Lake, WA, Australia) (Table 1). The geographic and climate information, soil characteristics and $\mathrm{N}$ fertiliser levels at each site are summarised in Table 1. A set of 24 Australian genotypes of spring wheat (Triticum aestivum L.) was cultivated (Table 2). The genotypes were composed of modern elite lines, and parents of mapping populations. Weed and insect control treatments followed standard practice for the region.

\section{Data collection and calculations}

Grain yield (GY, $\mathrm{kg} \mathrm{ha}^{-1}$, determined at harvest time when moisture content was around $15 \%$ ), and NUE (GY per unit of $\mathrm{N}$ supplied, $\mathrm{kg} \mathrm{GY} \mathrm{kg} \mathrm{kg}^{-1} \mathrm{~N}$ ) were measured at all sites. Residual nitrogen was not included in the calculations of NUE (Moll et al. 1982) but it could affect the value of calculated NUE. In this study, we define NUE Stability as a measure of the response of a genotype's NUE to N supply for a single site/season; this was calculated as NUE at high $\mathrm{N}-\mathrm{NUE}$ at low $\mathrm{N}$ $\left(\mathrm{kg} \mathrm{ha}^{-1}\right)$. For each site, measures of NUE Stability were then converted to a Stability Ranking, on a scale of 1 to $8(1=$ high NUE Stability; $8=$ low NUE Stability $)$. At two of the sites (CUM 11 and ROS 11), we measured grain protein content by using near infrared spectroscopy, and the efficiency of $\mathrm{N}$ for protein yield (NUE-PY; protein yield per unit of $\mathrm{N}$ supplied, $\mathrm{kg} \mathrm{PY} \mathrm{kg}^{-1} \mathrm{~N}$ ) was calculated. Protein yield (PY, protein (\%) multiplied by $\mathrm{GY}$ ) was divided to $\mathrm{N}$ fertilisation. At physiological maturity, plant height $(\mathrm{cm}$, to the base of the spike) and above-ground harvest index (HI; the proportion of grain dry matter to total shoot dry matter, \%) was measured at one site (ROS 11). Harvest index was determined on single plants harvested from a $50 \mathrm{~cm}$ interval sampled from the two central rows in each plot.

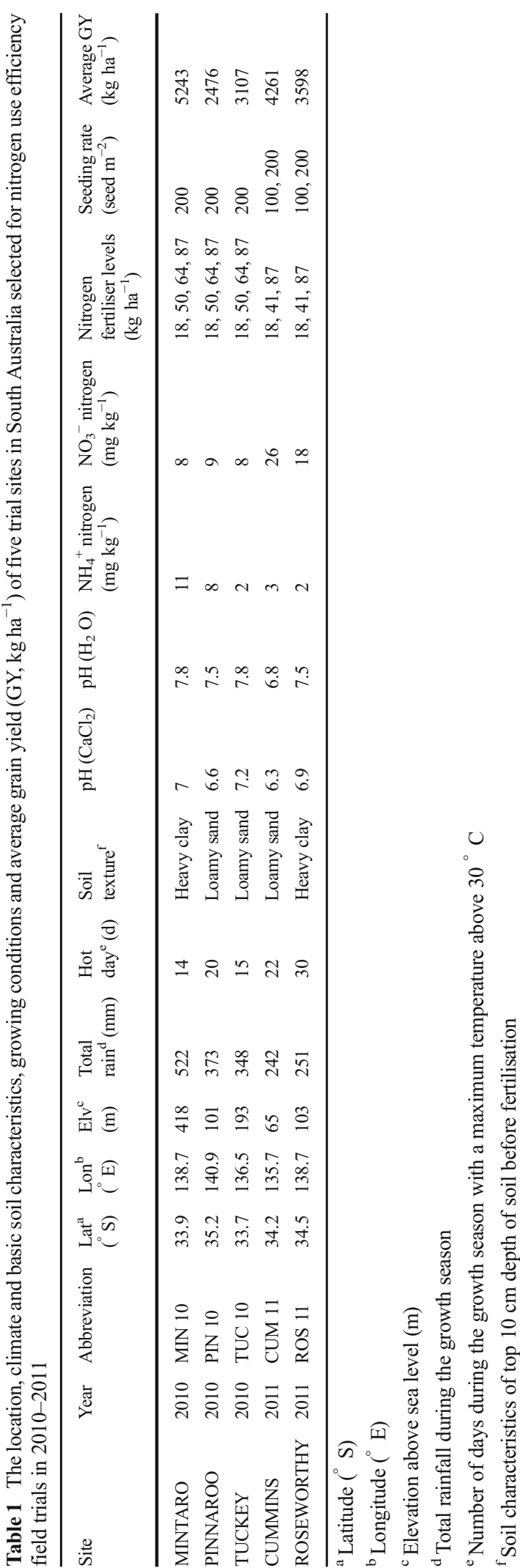


Table 2 Spring wheat genotypes studied at five nitrogen use efficiency field trial site locations, 2010-2011

\begin{tabular}{|c|c|}
\hline Genotype $^{\mathrm{a}}$ & Abbreviation \\
\hline AGT-KATANA & KAT \\
\hline AXE & AXE \\
\hline CATALINA & CAT \\
\hline CORACK & CORA \\
\hline CORRELL & $\mathrm{COR}$ \\
\hline DERRIMUT & DER \\
\hline DRYSDALE & DRY \\
\hline ELMORE CL PLUS & ELM \\
\hline ESPADA & ESP \\
\hline ESTOC & EST \\
\hline EXCALIBUR & $\mathrm{EXC}$ \\
\hline FRAME & FRA \\
\hline GLADIUS & GLA \\
\hline GRENADE CL PLUS & GRE \\
\hline JANZ & JAN \\
\hline JUSTICA CL PLUS & JUS \\
\hline KORD CL PLUS & KOR \\
\hline KUKRI & KUK \\
\hline MACE & MAC \\
\hline RAC0875 & $\mathrm{R} 875$ \\
\hline RAC1569 & R1569 \\
\hline SABEL CL PLUS & $\mathrm{SAB}$ \\
\hline SCOUT & $\mathrm{SCO}$ \\
\hline WAGT 104 & WAG \\
\hline WYALKATCHEM & WYA \\
\hline YITPI & YIT \\
\hline YOUNG & YOU \\
\hline
\end{tabular}

${ }^{\mathrm{a}}$ ELM, GRE and SCO were not planted at MIN 10, PIN 10 and TUC 10. Similarly, DER, DRY and WAG were not grown at CUM 11 and ROS 11

\section{Statistical analysis}

All data were used in spatial analysis to estimate the predicted means and standard error of the means of the traits of interest using the Restricted Maximum Likelihood (REML) directive in GenStat (VSN international, Version 15) (Payne 2009). The predicted means were used to compare genotypes for traits associated with NUE across different sites and $\mathrm{N}$ treatments. The factors that were tested included the effect of genotype $(\mathrm{G}), \mathrm{N}$ fertilisation $(\mathrm{N})$, seeding rate (SR) at two sites, and their interactions (Table 3). Phenotypic correlation coefficients, according to the predicted means, were determined for the traits of interest at three replicates at each site and are presented in Table 4.

\section{Results}

Significant genetic variation existed for GY and consequently NUE at each of the trial sites (Table 3). In this study, the average GY was highest at MIN 10 and lowest at PIN 10 (Table 1). The effect of $\mathrm{N}$ treatment was significant for GY at all sites. A genotype-by-N treatment interaction $(\mathrm{G} \times \mathrm{N})$ for $\mathrm{GY}$ was significant only at ROS $11(P<0.05)$. For NUE, $\mathrm{G}$ and $\mathrm{N}$ application level had significant effects $(P<0.001)$ at all sites, although the effects were not consistent. Genotypes responded differently to $\mathrm{N}$ fertilisation, showing a significant interaction of $\mathrm{G} \times \mathrm{N}$ for NUE at all sites except TUC 10.

An interaction of seeding rate (SR) with $\mathrm{N}$ treatment for GY and NUE was significant at both sites where this was tested, CUM 11 and ROS 11. Nitrogen use efficiency for protein yield (NUE-PY; $\mathrm{kg}$ grain protein $\mathrm{N}$ per $\mathrm{kg}$ $\mathrm{N}$ supplied) was also determined at these two sites and was influenced by $\mathrm{G}, \mathrm{N}$ treatment and $\mathrm{SR}$, but a $\mathrm{G} \times \mathrm{N}$ interaction was only observed at CUM 11. Nitrogen use efficiency for PY was highly correlated with NUE at CUM 11 ( $r=0.79$, Table 4). At ROS 11, where genotypes were scored for plant height, the effects of G, SR, $\mathrm{G} \times \mathrm{N}, \mathrm{G} \times \mathrm{SR}$ and $\mathrm{N} \times \mathrm{SR}$ interaction were significant for height, while $\mathrm{N}$ was not significant (Table 3). There was genotypic variation for HI at ROS 11 (Table 3). Although $\mathrm{N}$ application did not have a significant effect on $\mathrm{HI}$, there was a significant effect of $\mathrm{G} \times \mathrm{N}$. There was no significant interaction of $\mathrm{G} \times \mathrm{N} \times \mathrm{SR}$ for any of the traits measured in this study (Table 3). Although the average correlation for variety performance for GY between sites was relatively large (0.52), the correlation between sites for $\mathrm{N}$ response was smaller (Table 4).

This study showed that genotypes with higher HI tended to also have higher NUE (Fig. 1 and online supplementary Table S1, showing data for one site and season). There was a reasonably strong relationship between HI and NUE at ROS $11\left(R^{2}=0.46\right.$; Fig. 1$)$.

Some wheat varieties showed consistent responses to $\mathrm{N}$ across sites. As expected, increased supply of $\mathrm{N}$ resulted in higher GY but reduced NUE (Fig. 2), giving negative values for NUE Stability. Between sites, MIN 10 showed the highest NUE at the high rate of $\mathrm{N}$ application, but this was much lower than the NUE 
Table 3 The significance ( $P$ - value) of genotype $(\mathrm{G}), \mathrm{N}$ treatment $(\mathrm{N})$, seeding rate (SR) and their interactions on grain yield $\left(\mathrm{GY}, \mathrm{kg} \mathrm{ha}^{-1}\right)$, nitrogen use efficiency (NUE, $\mathrm{kg} \mathrm{GY} \mathrm{kg}^{-1} \mathrm{~N}$ ), nitrogen use efficiency for protein yield (NUE-PY, $\mathrm{kg} \mathrm{PY} \mathrm{kg}^{-1} \mathrm{~N}$ ), plant height $(\mathrm{H}, \mathrm{cm})$ and harvest index $(\mathrm{HI}, \%)$ measured in nitrogen use efficiency field trials in South Australia, 2010-2011

\begin{tabular}{|c|c|c|c|c|c|c|c|c|}
\hline \multirow[t]{2}{*}{ Trait } & \multirow[t]{2}{*}{ Site } & \multicolumn{7}{|l|}{ Factors } \\
\hline & & G & $\mathrm{N}$ & SR & $\mathrm{G} \times \mathrm{N}$ & $\mathrm{G} \times \mathrm{SR}$ & $\mathrm{N} \times \mathrm{SR}$ & $\mathrm{G} \times \mathrm{N} \times \mathrm{SR}$ \\
\hline \multirow[t]{5}{*}{ GY } & MIN 10 & $<0.001$ & $<0.001$ & - & 0.123 & - & - & - \\
\hline & PIN 10 & $<0.001$ & $<0.001$ & - & 0.479 & - & - & - \\
\hline & TUC 10 & $<0.001$ & $<0.001$ & - & 0.672 & - & - & - \\
\hline & CUM 11 & $<0.001$ & $<0.001$ & $<0.001$ & 0.128 & 0.433 & 0.002 & 0.950 \\
\hline & ROS 11 & $<0.001$ & $<0.001$ & $<0.001$ & 0.003 & 0.013 & 0.025 & 0.652 \\
\hline \multirow[t]{5}{*}{ NUE } & MIN 10 & $<0.001$ & $<0.001$ & - & $<0.001$ & - & - & - \\
\hline & PIN 10 & $<0.001$ & $<0.001$ & - & $<0.001$ & - & - & - \\
\hline & TUC 10 & $<0.001$ & $<0.001$ & - & 0.250 & - & - & - \\
\hline & CUM 11 & $<0.001$ & $<0.001$ & $<0.001$ & $<0.001$ & 0.745 & $<0.001$ & 1.000 \\
\hline & ROS 11 & $<0.001$ & $<0.001$ & $<0.001$ & 0.018 & 0.258 & $<0.001$ & 0.661 \\
\hline \multirow[t]{2}{*}{ NUE-PY } & CUM 11 & $<0.001$ & $<0.001$ & $<0.001$ & 0.002 & 0.609 & 0.008 & 0.999 \\
\hline & ROS 11 & $<0.001$ & $<0.001$ & $<0.001$ & 0.464 & 0.233 & 0.058 & 0.614 \\
\hline $\mathrm{H}$ & ROS 11 & $<0.001$ & 0.588 & $<0.001$ & $<0.001$ & 0.003 & 0.001 & 0.229 \\
\hline $\mathrm{HI}$ & ROS 11 & $<0.001$ & 0.515 & 0.458 & 0.002 & 0.771 & 0.533 & 0.967 \\
\hline
\end{tabular}

Not significant at $P>0.05 ; 5 \%$ significant at $P<0.05 ; 1 \%$ significant at $P<0.01$

observed for the low $\mathrm{N}$ treatment. With increasing $\mathrm{N}$ application, NUE differed significantly in most sites except at TUC 10 (Fig. 2). In order to investigate the response of NUE to $\mathrm{N}$ supply across environments, NUE Stability was calculated for genotypes at four trial sites where there was a significant $\mathrm{G} \times \mathrm{N}$ effect (MIN

Table 4 Pairwise correlations between sites for grain yield (GY, $\mathrm{kg} \mathrm{ha}^{-1}$ ) and nitrogen use efficiency (NUE, $\mathrm{kg} \mathrm{GY} \mathrm{kg}^{-1} \mathrm{~N}$ ). Correlations are also given for nitrogen use efficiency (NUE) Stability (NUE at high $\mathrm{N}-\mathrm{NUE}$ at low N), between sites showing
10, PIN 10, CUM 11, and ROS 11). Figure 3 shows the NUE Stability Rankings of eight genotypes for NUE at each of the sites. Overall, Mace and RAC1569 ranked highly and were stable for NUE across sites and N treatments, while Frame, Kord CL Plus and Catalina ranked poorly.

significant $\mathrm{G} \times \mathrm{N}$ for NUE across nitrogen treatments. Each trial was run using a split plot design with three replicates. The GY data was corrected using spatial analysis

\begin{tabular}{cllll}
\hline Trait & Site & MIN 10 & PIN 10 & TUC 10 \\
\hline \multirow{2}{*}{ GY } & PIN 10 & 0.67 & & \\
& TUC 10 & 0.37 & 0.38 & 0.55 \\
& CUM 11 & 0.73 & 0.56 & 0.15 \\
NUE & ROS 11 & 0.70 & 0.63 & - \\
& PIN 10 & 0.61 & 0.47 & - \\
CUM 11 & 0.54 & 0.54 & 0.19 \\
NUE Stability & ROS 11 & 0.58 & & - \\
& PIN 10 & 0.41 & 0.17 & - \\
\end{tabular}




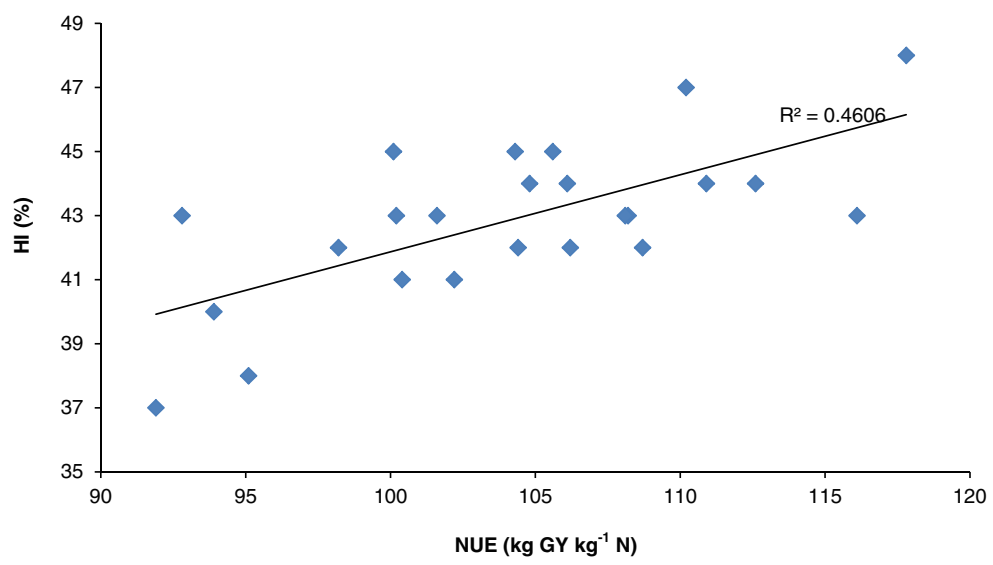

Fig. 1 Relationship between harvest index (HI, \%) and nitrogen use efficiency (NUE, $\mathrm{kg} \mathrm{GY} \mathrm{kg}^{-1} \mathrm{~N}$ ) of 24 wheat genotypes at a single site in South Australia in 2011 (ROS 11). Source data listing the values for each genotype are provided in supplementary Table S1

\section{Discussion}

In this study, we observed low GY at low $\mathrm{N}$ supply across sites, consistent with the results of Abe et al. (2013); Cormier et al. (2013) and Pang et al. (2013). Unlike previous studies, however, here we explored genetic variation for NUE under low-yielding conditions where productivity is severely limited by moisture stress. Under these production conditions, $\mathrm{N}$ is often applied at or near sowing and the ability of the crop to manage $\mathrm{N}$ uptake and use $\mathrm{N}$ during crop establishment and early growth is critical. Excessive early vigour and biomass production in response to the available $\mathrm{N}$ can be a liability late in the season when water is severely limited. A set of 24 modern wheat varieties were ranked for NUE across trial sites to reveal lines showing stable performance across environments. In line with previous reports (Bertin and Gallais 2001; An et al. 2006; Asplund et al. 2014), our study demonstrated that there is significant genetic variation for NUE between wheat genotypes. Abe et al. (2013) also demonstrated significant genetic variation for GY and measured NUE component traits among maize hybrids at increasing rates of $\mathrm{N}$ application. In another recent study, the genetic progress for NUE in winter wheat was assessed in two hundred and twenty-five elite European varieties at four sites under two levels of $\mathrm{N}$ application (Cormier et al. 2013). Significant effects of genotype were found for $\mathrm{GY}$ and NUE at all sites, and $\mathrm{G} \times \mathrm{N}$ interactions were significant at some sites. Peng et al. (2013) determined the critical soil mineral $\mathrm{N}$ concentration to achieve optimum GY in maize in a three-year field trial at three $\mathrm{N}$ treatments. Their findings concur with our study where we found significantly higher GY at high levels of $\mathrm{N}$ treatment relative to the low $\mathrm{N}$ treatments.

The genetic basis for variation in NUE has been studied in NUE-Quantitative Trait Loci (QTL) studies. For example, Bertin and Gallais (2001) in a study of genetic variation for NUE in a set of maize recombinant inbred lines, found significant QTL for GY at high N and low levels of N. In addition, Asplund et al. (2014) evaluated a new concept for assessment of NUE in six

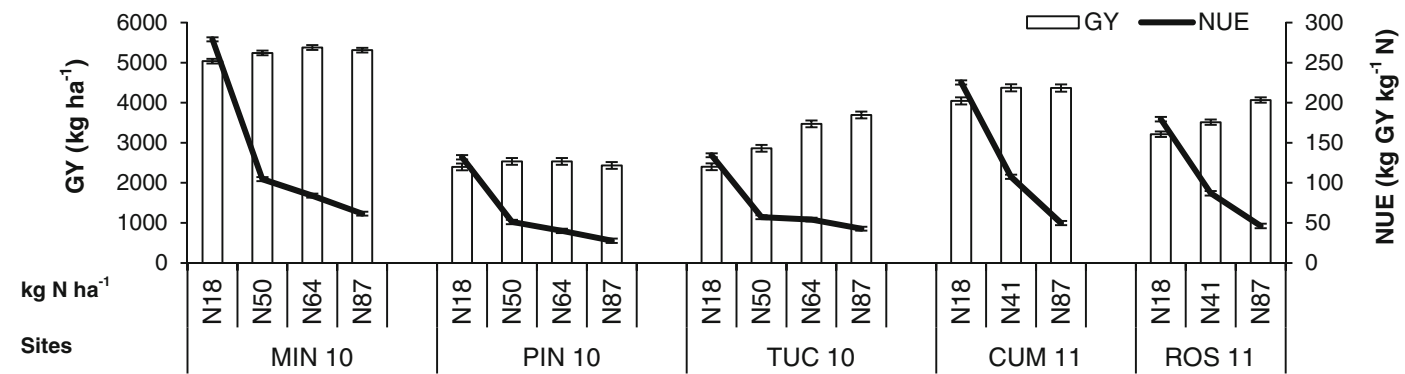

Fig. 2 The average grain yield (GY, $\mathrm{kg} \mathrm{ha}^{-1}$ ) and nitrogen use efficiency (NUE, $\mathrm{kg} \mathrm{GY} \mathrm{kg}^{-1} \mathrm{~N}$ ) of 24 wheat genotypes grown with varied levels of $\mathrm{N}$ fertilisation at five sites in South Australia,
2010-2011. Vertical error bars represent the standard errors of the predicted means after spatial analysis 


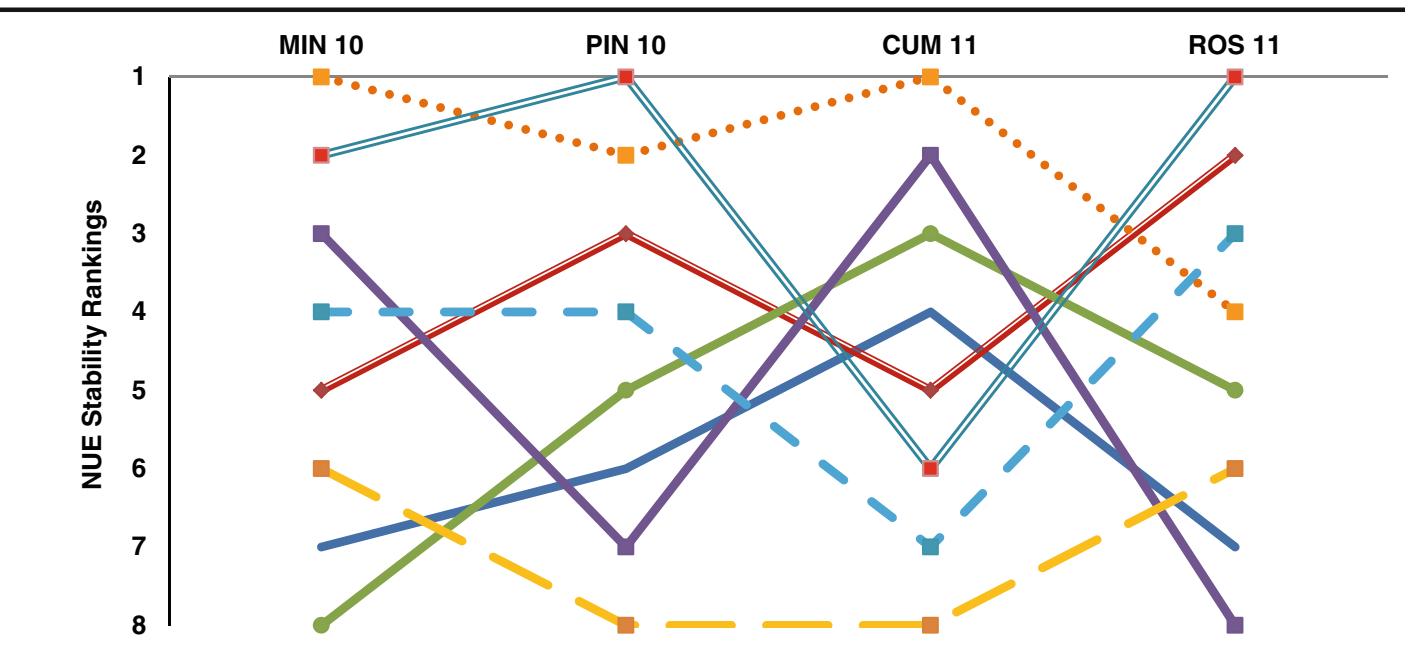

Genotype

FRA

$\mathrm{KOR} \cdot \cdots \cdot \mathrm{MAC}=\square \mathrm{R} 1569$

Fig. 3 Nitrogen use efficiency (NUE) Stability Rankings ( 1 = high NUE Stability; $8=$ low NUE Stability) of selected wheat genotypes at sites where there was significant $\mathrm{G} \times \mathrm{N}$ interaction for NUE

spring wheat varieties under field and controlled conditions. However, the impact of environment (the interaction of climate, soil, water availability and other factors) and $\mathrm{G} \times \mathrm{E}$ on NUE and $\mathrm{N}$ responsiveness confirms that achieving genetic gains for NUE will be challenging (Ortiz-Monasterio et al. 1997; Hirel et al. 2007). In our study it is likely that variation in the timing and amount of rainfall, as well as other abiotic stresses such as hot days (Table 1), influenced the value of $\mathrm{N}$ application at each site, and the relative response of each genotype to N supply. For instance, at MIN 10, GY was, on average, higher than other sites due to higher rainfall and fewer hot days during the growth season. However, GY was also relatively high at CUM 11 where there was lower rainfall and more days with high temperature. Soil conditions and $\mathrm{N}$ availability could have affected the final productivity at this site. The lowest GY was recorded at PIN 10, and could be related to the sub-optimal rainfall and high number of hot days with poor soil $\mathrm{N}$ at this site (Table 1). Our results showed the effect of the interaction between environmental factors and $\mathrm{N}$ supplied; particularly the effects of both water and $\mathrm{N}$ availability on productivity at the different sites. Interestingly, seeding rate was found to interact with $\mathrm{N}$ supply and genotype, although there was no $\mathrm{G} \times \mathrm{N} \times \mathrm{SR}$ interaction. This result needs to be confirmed, as it was only tested at two sites with a limited set of genotypes, but if correct it helps to simplify the challenges of improving NUE in wheat. Geleta et al. (2002) demonstrated that different genotypes did not necessarily show the same response for both GY and SR. GY also varies at different $\mathrm{N}$ levels. Extensive interaction between $\mathrm{SR}$ and $\mathrm{N}$ would hamper improvement for GY under variable N. Therefore, the fewer interacting factors the more manageable the task of improvement for complex traits such as NUE.

Kanampiu et al. (1997) found that low N loss was associated with high $\mathrm{HI}$ and low forage yields in winter wheat which resulted in high NUE. Similarly, in our study genotypes with high HI had higher NUE at one of the sites (Fig. 1 and online supplementary Table S1). With respect to plant height, taller genotypes at this site showed, on average, lower NUE. This observation is also in agreement with other studies. For instance, Guarda et al. (2004) reported that reduced height led to an increase in HI, and proposed that this was due, at least partially, to more efficient partitioning of photosynthates to the developing spike. As expected, the protein content of genotypes responded differently to $\mathrm{N}$ levels for the two sites where this was measured demonstrating an interaction between $\mathrm{N}$ and environmental factors. There was a strong correlation between NUE and NUE-PY ( $r=0.79$, Table 4), suggesting that NUE-PY may be considered as a component of NUE in plant breeding. The effects of NUE on both grain quantity and quality characteristics need to be considered (Peterson et al. 1992; Uribelarrea et al. 2009). 
Some genotypes which responded strongly to $\mathrm{N}$ fertilisation, were low yielding and had low NUE at low N supply (for example, Kord CL Plus at PIN 10, Axe at CUM 11, Grenade at ROS 11). The opposite was also true, where some varieties such as Corack at CUM 11, Excalibur at MIN 10, Wyalkatchem at PIN 10, RAC875 at ROS 11 and TUC 10 and Frame at TUC 10, showed high GY at low $\mathrm{N}$ supply and no strong response to increased $\mathrm{N}$ application. These results confirm the $\mathrm{G} \times \mathrm{E}$ effects on the performance of different genotypes and support a previous study in oilseed rape (Ulas et al. 2013) which suggested that efficiency and responsiveness may need to be considered independently. The negative association between efficiency and responsiveness may relate to the ability of plants to manage early growth and $\mathrm{N}$ uptake to limit stress susceptibility late in the season. The results could reflect two approaches to deal with this problem. Genotypes such as Kord CL, Axe and Grenade may use the available $\mathrm{N}$ to build biomass but are then limited for $\mathrm{N}$ late in the season which results in low yields and low NUE. The second group of genotypes may be better able to match biomass production to $\mathrm{N}$ supply, allowing them to restrict early growth to ensure adequate $\mathrm{N}$ will be available during flowering and grain filling. These lines are able to show a consistent response to $\mathrm{N}$ across multiple environments. To improve NUE, both efficiency and $\mathrm{N}$ response should be considered, making this second group particularly interesting. The present and previous studies emphasised the need for a clear definition of N responsiveness and NUE, especially for breeding objectives. Possible objectives could include selection of genotypes with the capability to maintain high yield under low $\mathrm{N}$ input, or developing genotypes with high $\mathrm{N}$ responsiveness and high NUE at high N supply.

In an effort to identify genotypes that have high NUE at both low and high $\mathrm{N}$ supply, the consistency of the $\mathrm{N}$ response is important. Breeders will aim to identify genotypes which show high and consistent NUE across $\mathrm{N}$ application levels and sites. In this study, we defined the NUE Stability of a wheat genotype as the difference in NUE at high and low levels of N supply for a specific site/season. Although NUE Stability showed smaller genetic correlations between sites than GY (Table 4), several genotypes were identified that ranked highly for NUE Stability across multiple sites/seasons At sites where a significant $\mathrm{G} \times \mathrm{N}$ effect was observed for NUE, Mace and RAC1569 consistently ranked highly for NUE Stability (Fig. 3), suggesting that these genotypes could be exploited by breeders for NUE improvement. Other genotypes showed large variation (inconsistent or low NUE Stability) between sites. For example, the NUE Stability Rankings of Frame varied between sites, and Kord CL Plus had low NUE Stability Rankings at most sites.

In conclusion, we identified genetic variation for NUE-related traits among a selection of modern Australian genotypes grown in low yielding environments. We were able to select and rank genotypes for NUE Stability, suggesting the potential use of this trait for $\mathrm{G} \times \mathrm{N}$ evaluation even across different yielding environments. Rankings for NUE Stability and NUEPY could be used to guide the selection of suitable parents for new mapping populations to dissect the genetic basis of the contrasting performance for NUE. Ultimately, knowledge of the genetics underlying traits associated with NUE will contribute to wheat breeding efforts to develop genotypes with improved NUE.

Acknowledgments The authors would like to thank the staff at Australian Grain Technologies (AGT) for planting and managing the NUE experiments. We also acknowledge Dr. Dion Bennett for his assistance and advice with field work, and Dr. Julie Hayes for critically reading the manuscript. This work was supported through funding from the Grains Research and Development Corporation, the Australian Research Council, The University of Adelaide and the Premier's Research and Industry Fund provided by the South Australian Government Department of Further Education, Employment, Science and Technology.

Open Access This article is distributed under the terms of the Creative Commons Attribution 4.0 International License (http://creativecommons.org/licenses/by/4.0/), which permits unrestricted use, distribution, and reproduction in any medium, provided you give appropriate credit to the original author(s) and the source, provide a link to the Creative Commons license, and indicate if changes were made.

\section{References}

Abe A, Menkir A, Moose SP, Adetimirin VO, Olaniyan AB (2013) Genetic variation for nitrogen-use efficiency among selected tropical maize hybrids differing in grain yield potential. J Crop Improv 27:31-52

An D, Su J, Liu Q, Zhu Y, Tong Y, Li J, Jing R, Li B, Li Z (2006) Mapping QTLs for nitrogen uptake in relation to the early growth of wheat (Triticum aestivum L.). Plant Soil 284:73-84

Angus J, Van Herwaarden A (2001) Increasing water use and water use efficiency in dryland wheat. Agron J 93:290-298

Asplund L, Bergkvist G, Weih M (2014) Proof of concept: nitrogen use efficiency of contrasting spring wheat varieties grown in greenhouse and field. Plant Soil 374:829-842 
Barbottin A, Lecomte C, Bouchard C, Jeuffroy M-H (2005) Nitrogen remobilization during grain filling in wheat. Crop Sci 45:1141-1150

Bertin P, Gallais A (2001) Genetic variation for nitrogen use efficiency in a set of recombinant inbred lines II - QTL detection and coincidences. Maydica 46:53-68

Brennan J, Hackett R, McCabe T, Grant J, Fortune R, Forristal P (2014) The effect of tillage system and residue management on grain yield and nitrogen use efficiency in winter wheat in a cool atlantic climate. Eur J Agron 54:61-69

Chen C, Westcott M, Neill K, Wichman D, Knox M (2004) Row configuration and nitrogen application for barley-pea intercropping in Montana. Agron J 96:1730-1738

Cooper M, DeLacy I, Basford K (1996) Relationships among analytical methods used to analyse genotypic adaptation in multi-environment trials. Plant adaptation and crop improvement, 193-224. CAB Int., Wallingford, UK

Coque M, Martin A, Veyrieras J, Hirel B, Gallais A (2008) Genetic variation for $\mathrm{N}$-remobilization and postsilking $\mathrm{N}$-uptake in a set of maize recombinant inbred lines. 3. QTL detection and coincidences. Theor Appl Genet 117:729-747

Cormier F, Faure S, Dubreuil P, Heumez E, Beauchêne K, Lafarge S, Praud S, Le Gouis J (2013) A multi-environmental study of recent breeding progress on nitrogen use efficiency in wheat (Triticum aestivum L.). Theor Appl Genet 126:3035-3048

Craswell E, Godwin D (1984) The efficiency of nitrogen fertilizers applied to cereals grown in different climates. Adv Nutr 1:1-55

FAO (2011) Current world fertilizer trends and outlook to 2015. ftp://ftp.fao.org/ag/agp/docs/cwfto15.pdf

Gallais A, Coque M (2005) Genetic variation and selection for nitrogen use efficiency in maize: a synthesis. Maydica 50: 531-547

Geleta B, Atak M, Baenziger P, Nelson L, Baltenesperger D, Eskridge K, Shipman M, Shelton D (2002) Seeding rate and genotype effect on agronomic performance and end-use quality of winter wheat. Crop Sci 42:827-832

Groos C, Robert N, Bervas E, Charmet G (2003) Genetic analysis of grain protein-content, grain yield and thousand-kernel weight in bread wheat. Theor Appl Genet 106:1032-1040

Guarda G, Padovan S, Delogu G (2004) Grain yield, nitrogen-use efficiency and baking quality of old and modern Italian bread-wheat cultivars grown at different nitrogen levels. Eur J Agron 21:181-192

Harrison R, Webb J (2001) A review of the effect of $\mathrm{N}$ fertilizer type on gaseous emissions. Adv Agron 73:65-108

Hirel B, Bertin P, Quilleré I, Bourdoncle W, Attagnant C, Dellay C, Gouy A, Cadiou S, Retailliau C, Falque M (2001) Towards a better understanding of the genetic and physiological basis for nitrogen use efficiency in maize. Plant Physiol 125:1258-1270

Hirel B, Le Gouis J, Ney B, Gallais A (2007) The challenge of improving nitrogen use efficiency in crop plants: towards a more central role for genetic variability and quantitative genetics within integrated approaches. J Exp Bot 58:2369-2387

Hodge A, Robinson D, Fitter A (2000) Are microorganisms more effective than plants at competing for nitrogen? Trends Plant Sci 5:304-308

Kanampiu FK, Raun WR, Johnson GV (1997) Effect of nitrogen rate on plant nitrogen loss in winter wheat varieties. J Plant Nutr 20:389-404
Laperche A, Devienne-Barret F, Maury O, Le Gouis J, Ney B (2006) A simplified conceptual model of carbon/nitrogen functioning for QTL analysis of winter wheat adaptation to nitrogen deficiency. Theor Appl Genet 113:1131-1146

Le Gouis J, Pluchard P (1996) Genetic variation for nitrogen use efficiency in winter wheat (Triticum aestivum L.). Euphytica 92:221-224

Le Gouis J, Béghin D, Heumez E, Pluchard P (2000) Genetic differences for nitrogen uptake and nitrogen utilisation efficiencies in winter wheat. Eur J Agron 12:163-173

Liao MT, Fillery IRP, Palta JA (2004) Early vigorous growth is a major factor influencing nitrogen uptake in wheat. Funct Plant Biol 31:121-129

Mizuta K, Matsumoto T, Hatate Y, Nishihara K, Nakanishi T (2004) Removal of nitrate-nitrogen from drinking water using bamboo powder charcoal. Bioresour Technol 95:255-257

Moll RH, Kamprath EJ, Jackson WA (1982) Analysis and interpretation of factors which contribute to efficiency of nitrogen-utilization. Agron J 74:562-564

Ortiz-Monasterio R, Sayre K, Rajaram S, McMahon M (1997) Genetic progress in wheat yield and nitrogen use efficiency under four nitrogen rates. Crop Sci 37:898-904

Pang J, Palta JA, Rebetzke GJ, Milroy SP (2013) Wheat genotypes with high early vigour accumulate more nitrogen and have higher photosynthetic nitrogen use efficiency during early growth. Funct Plant Biol 41:215-222

Pathak RR, Ahmad A, Lochab S, Raghuram N (2008) Molecular physiology of plant nitrogen use efficiency and biotechnological options for its enhancement. Curr Sci 94:1394-1403

Payne RW (2009) GenStat, wiley interdisciplinary reviews. Comput Stat 1:255-258

Peng Y, Yu P, Li X, Li C (2013) Determination of the critical soil mineral nitrogen concentration for maximizing maize grain yield. Plant Soil 372:41-51

Peterson C, Graybosch R, Baenziger P, Grombacher A (1992) Genotype and environment effects on quality characteristics of hard red winter wheat. Crop Sci 32:98-103

Podlich D, Cooper M, Basford K, Geiger H (1999) Computer simulation of a selection strategy to accommodate genotype environment interactions in a wheat recurrent selection programme. Plant Breed 118:17-28

Raun WR, Johnson GV (1999) Improving nitrogen use efficiency for cereal production. Agron J 91:357-363

Sadras VO, Lawson C, Hooper P, McDonald GK (2012) Contribution of summer rainfall and nitrogen to the yield and water use efficiency of wheat in mediterranean-type environments of South Australia. Eur J Agron 36:41-54

Serrano L, Filella I, Penuelas J (2000) Remote sensing of biomass and yield of winter wheat under different nitrogen supplies. Crop Sci 40:723-731

Sylvester-Bradley R, Kindred DR (2009) Analysing nitrogen responses of cereals to prioritize routes to the improvement of nitrogen use efficiency. J Exp Bot 60:1939-1951

Ulas A, Behrens T, Wiesler F, Horst WJ (2013) Does genotypic variation in nitrogen remobilisation efficiency contribute to nitrogen efficiency of winter oilseed-rape cultivars (Brassica napus L.)? Plant Soil 371:463-471

Uribelarrea M, Crafts-Brandner SJ, Below FE (2009) Physiological $\mathrm{N}$ response of field-grown maize hybrids (Zea mays L.) with divergent yield potential and grain protein concentration. Plant Soil 316:151-160 